ISSN (print): 1698-6180. ISSN (online): 1886-7995

www.ucm.es/info/estratig/journal.htm

Journal of Iberian Geology 36 (2) 2010: 193-204

doi:10.5209/rev_JIGE.2010.v36.n2.7

\title{
Vertebrate fauna at the Allosaurus fossil-site of Andrés (Upper Jurassic), Pombal, Portugal
}

\author{
La fauna de vertebrados del yacimiento con Allosaurus de Andrés \\ (Jurásico Superior), Pombal, Portugal
}

\author{
E. Malafaia ${ }^{1,2,3 *}$, F. Ortega ${ }^{4,3}$, F. Escaso ${ }^{4,5,3}$, P. Dantas ${ }^{1,2,3}$, N. Pimentel ${ }^{6}$, J. M. Gasulla ${ }^{5}$, B. Ribeiro ${ }^{1}$, F \\ Barriga $^{1}$, J. L. Sanz ${ }^{5}$ \\ ${ }^{1}$ Museu Nacional de História Natural (Universidade de Lisboa). Rua da Escola Politécnica, 58. 1250-102 Lisboa, \\ Portugal. \\ ${ }^{2}$ Laboratório de História Natural. Câmara Municipal da Batalha, Apart. 116. 2441-901, Batalha, Portugal \\ ${ }^{3}$ ALT-Sociedade de História Natural, Torres Vedras. Apartado 25, 2564-909 Torres Vedras, Portugal. \\ ${ }^{4}$ Grupo de Biología. Departamento de Física Matemática y de Fluidos, Facultad de Ciencias, UNED, \\ Paseo Senda del Rey 9, 28040 Madrid, Spain \\ ${ }^{5}$ Unidad de Paleontología, Facultad de Ciencias, Universidad Autónoma de Madrid, Cantoblanco, \\ 28049 Madrid, Spain. \\ ${ }^{6}$ Centro de Geologia da Universidade de Lisboa. Faculdade de Ciências, Campo Grande, Edifíicio C6. \\ 1749-016 Lisboa, Portugal. \\ Corresponding author: E. Malafaia,emalafaia@gmail.com
}

Received: 17/11/09 / Accepted: 30/06/10

\begin{abstract}
An overview of the faunistic diversity of the Andrés fossil-site from the Portuguese Upper Jurassic is presented. This work provides a preliminary approach on the vertebrate fauna known at present. Although this quarry is known since the 1990's, due to the description of the first robust evidence of a member of the neotetanuran genus Allosaurus outside North America, the results presented here are mainly derived from the analysis of the elements found during the second and third field seasons in 2005.

At the moment, among the material collected from Andrés it was identified remains that represent a diverse vertebrate fauna, including fishes, sphenodonts, crocodylomorphs, pterosaurs, and at least, seven distinct dinosaur forms. The recovery of this diverse and abundant osteological collection from one unique fossil-site is noteworthy for the Upper Jurassic Portuguese record, and only comparable with those from the Guimarota coalmine. Due to these two features plus the good preservation of the fossils, the Andrés quarry may be a site of reference for the analysis of vertebrate ecosystems from the Portuguese Upper Jurassic. Dinosaur elements are the most abundant fossils, and among them it is particularly common the presence of remains identified as Allosaurus. These new evidences allow testing the previous phylogenetical hypothesis ascribing the firsts theropod remains from Andrés to $A$. fragilis, a species described in synchronic levels of the North American Morrison Formation.
\end{abstract}


The similarity between the Allosaurus remains collected in Andrés and some specimens from the Morrison Formation seems to point the existence of a genetic flow between some continental vertebrates on both sides of the proto-north Atlantic during the Upper Jurassic. Favourable tectonic conditions for the occurrence of punctual contacts between the two continents is, at present, the best scenario for explain this situation.

Keywords: Upper Jurassic, Portugal, Lusitanian Basin, North America, Morrison Formation, Paleobiogeography

\section{Resumen}

Se presenta un análisis de la diversidad faunística del yacimiento de Andrés en el Jurásico Superior de la Cuenca Lusitánica. El presente trabajo pretende establecer un análisis preliminar de la fauna de vertebrados identificada en el yacimiento hasta la fecha. Aunque conocido desde la decada de 1990, debido a la descripción de la primera evidencia robusta de un neotetanuro del género Allosaurus fuera de Norteamérica, los resultados presentados derivan principalmente del análisis de elementos encontrados durante la segunda y tercera campañas de excavación en 2005.

Hasta el momento han sido identificados entre el material recogido en Andrés, representantes de diversos taxones de vertebrados que incluyen peces, esfenodontos, crocodilomorfos, pterosaurios y, al menos, siete formas distintas de dinosaurios. La presencia de esta diversidad y abundancia de restos osteológicos en el mismo yacimiento representa una situación única en el registro del Jurásico Superior portugués, tan sólo comparable a la del yacimiento clásico de la mina de carbón de Guimarota. Atendiendo a estas dos características y a la buena preservación de los fósiles, el yacimiento de Andrés puede ser considerado como una localidad de referencia para el estudio de los ecosistemas con vertebrados del Jurásico Superior portugués. Los restos de dinosaurios son los fósiles más abundantes y, entre ellos, son particularmente comunes los asignables a Allosaurus. Estas nuevas evidencias proporcionan importantes datos para probar la hipótesis filogenética propuesta previamente que asigna el primer terópodo descubierto en Andrés a A. fragilis, una especie descrita en niveles sincrónicos de la Formación Morrison en Norteamérica.

La similitud entre los restos de Allosaurus recogidos en Andrés y algunos de los ejemplares de la Formación Morrison, sugiere la existencia de un flujo genético entre algunos vertebrados continentales de ambos lados del proto-Atlántico norte durante el Jurásico Superior. La existencia de condiciones tectónicas favorables para la existencia de contactos puntuales entre los dos continentes es actualmente el mejor escenario para explicar esta situación.

Palabras clave: Jurásico Superior, Portugal, Cuenca Lusitánica, Norteamérica, Formación Morrison, Paleobiogeografia

\section{Introduction}

The quarry is found in the small township of Andrés (Pombal municipality, district of Leiria, Portugal) some $172 \mathrm{~km}$ to the north from Lisbon and $35 \mathrm{~km}$ to the north from Leiria (Fig. 1a). Stratigrafically, the site is located at the Meso-Cenozoic fringe of central-western Portugal in the northern sector of the Lusitanian Basin.

The discovery of the quarry in 1988 occurred during the construction of a tool warehouse and that year was performed a first palaeontological intervention. It was collected a block of rock containing part of the pelvic girdle and hindlimb elements of a large neotetanuran theropod. In the description of the specimen, it was proposed as the first robust evidence of a member of the species $\mathrm{Al}$ losaurus fragilis outside North America (Pérez-Moreno et al., 1999).

In 2005, it was reactivated the fieldworks at the Andrés quarry. On the sequence of this, it was recognized a great accumulation of a relatively diverse fauna of vertebrates. The diversity, abundance and good conditions of preservation in the quarry are not usual from the Portuguese Upper Jurassic and are, somehow, in the line with the classical Guimarota coalmine, in Leiria (Martin and Krebs, 2000).

\section{Geological setting}

The sedimentary deposits in which the quarry is included are interpreted as corresponding to the upper levels of the Alcobaça Formation (Complexo de Vale de Lagares) uppermost Kimmeridgian-lowermost Tithonian in age (Teixeira et al., 1966, 1968). However, the quarry is more favourably included in the unity designated as Bombarral Formation (="Grés Superiores"), which is partially equivalent to the Alcobaça Formation in the northern sector of the Lusitanian Basin (Fig. 1b, d). The "Grés Superiores" is a diachronic unity, at least in its lowermost part, but most probably lower to upper Tithonian in age (Marques et al., 1992; Manuppella et al., 1998, 2000). This unity is composed essentially by fine-grained mudsandstones, sometimes micaceous, with intercalations of some levels of marls, silts and clays, sometimes with abundant calcareous or limonitic nodules (Manuppella et al., 1974, 1978). At the moment, attend to the previous argumentation, the sediments in the Andrés site are interpreted as ?upper Kimmeridgian - Tithonian in age.

The sedimentary deposits in the area of the quarry essentially comprehend levels of massive fine sandstones, sometimes micaceous with parallel lamination, and with abundant carbonized vegetal remains. Intercalated in the 


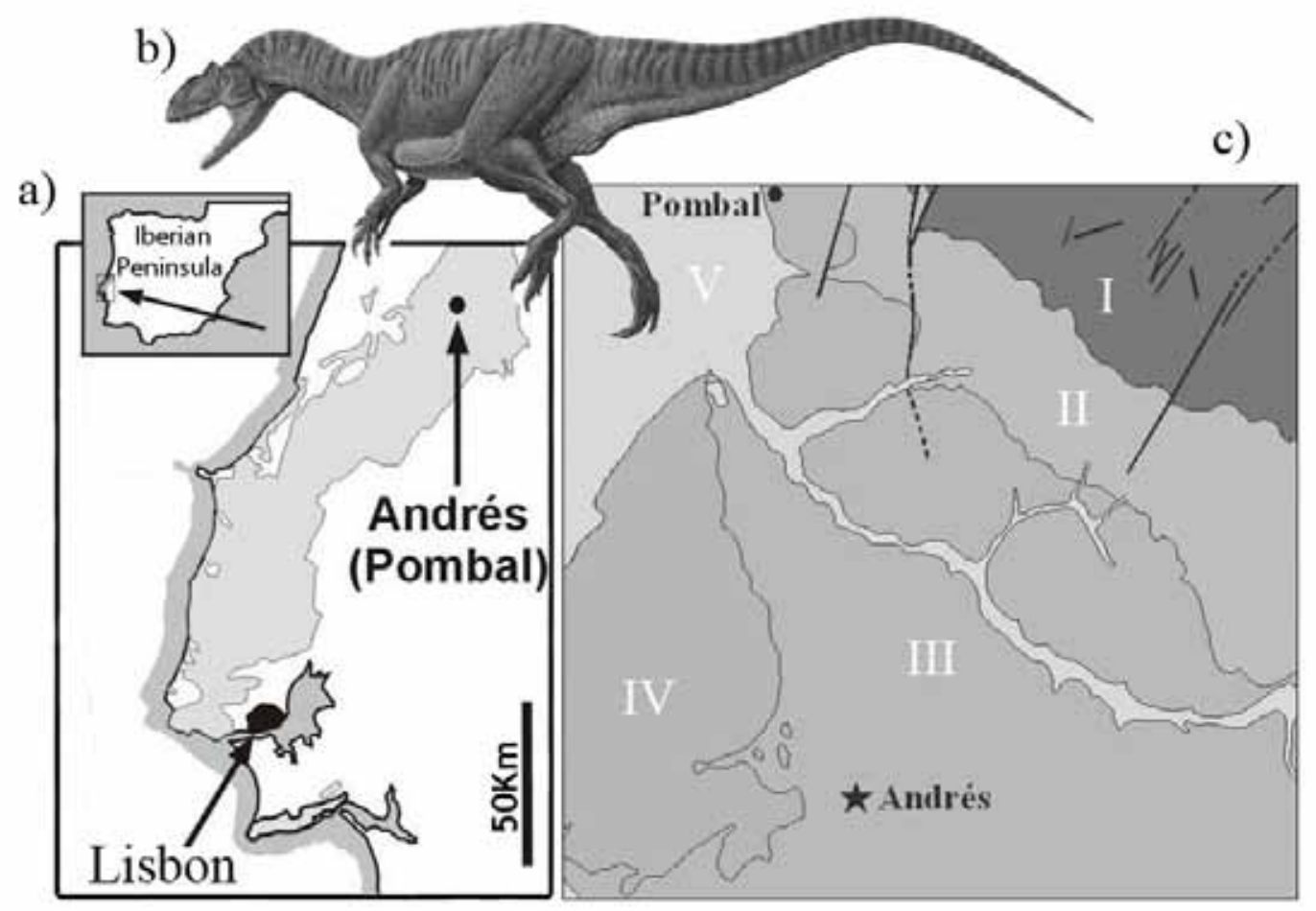

d)

\begin{tabular}{|c|c|c|c|}
\hline \multicolumn{2}{|c|}{ Cronostratigraphy } & \multicolumn{2}{|r|}{ Litostratigraphy } \\
\hline \multirow{4}{*}{ 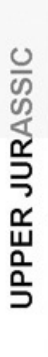 } & Tithonian & \multirow{2}{*}{ 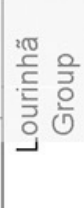 } & $\begin{aligned} & \text { Bombarral Fm. } \\
& \text { (= Grés Superiores) }\end{aligned}$ \\
\hline & Kimmeridgian & & Alcobaça Fm. \\
\hline & \multirow[t]{2}{*}{ Oxfordian } & \multicolumn{2}{|r|}{ Montejunto Fm. } \\
\hline & & \multicolumn{2}{|r|}{ Cabaços Fm. } \\
\hline
\end{tabular}

sandstones fine levels and lens of red and grey clays occur, with abundant freshwater bivalves and some gastropods. This sequence passes laterally to levels of red massive mudstones.

The osteological remains, mainly the Allosaurus elements, were found in a level of fine micaceous sandstones with abundant carbonated concretions. These concretions are frequently associated with skeletal remains and in many cases with dense accumulations of them, pointing to an origin related with processes of soft tissues decomposition. In a lower sandy level with abundant carbonized remains, in some areas of the quarry, a few mainly isolated sauropod remains were found. In some clay levels and associated with clay lens, small osteological remains (fish scales, crocodile elements, dinosaur teeth, bones of
Fig. 1.- a) Geographic localization of the Andrés fossil-site (Pombal, Upper Jurassic) on the central-western Portuguese area. The plotted area corresponds to the Lusitanian Basin. b) Simplified geological map around the Andrés locality. Legend: Upper Jurassic (I. - Oxfordian; II. - lower Kimmeridgian; III. - ? uppermost Kimmeridgian -Tithonian); IV.- Lower Cretaceous; V.- Cenozoic. c) Allosaurus fragilis d) Chronolitostratigraphic table. The plotted area marks the position of the Andrés quarry.

Fig. 1.- a) Localización geográfica del yacimiento de Andrés (Pombal, Jurásico Superior) en la región centro-occidental portuguesa. El área tramada corresponde a la Cuenca Lusitánica. b) Mapa geológico simplificado del entorno de la localidad de Andrés. Leyenda: Jurásico Superior (I. - Oxfordiense; II. - Kimmeridgiense inferior; III. - ? Kimmeridgiense superior - Titónico); IV. - Cretácico Inferior; V. Cenozoico. c) Allosaurus fragilis d) Tabla cronolitostratigráfica. El área tramada marca la posición estratigráfica de los sedimentos en el yacimiento de Andrés.

sphenodonts) are very abundant.

Field analysis of the sedimentary deposits allowed the recognition of its main features and its palaeoenvironmental reconstruction. Coarse sandy lag deposits represent the erosional cut-off and initial filling of fluvial channels, whereas medium to fine sandy layers with low-angle cross-bedding and sigmoidal geometries represent channelized low-energy flows, filling-up those channels. Fine sands, with thick asymmetrical lensoidal geometries, frequently laminated and intercalated with millimetre to centimetre thick silts and clays, represent overbank crevasse-splays. Fine-grained deposits, in thick tabular geometries with massive or laminated clays and silts, mostly reddish or mottled, represent flood-plain overbank accumulations. 

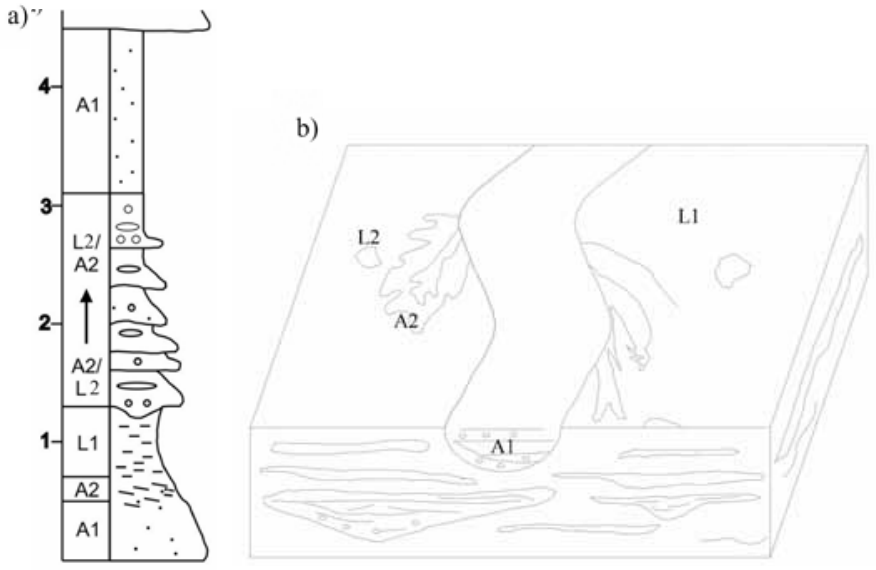

Fig. 2.- a) Lithostratigraphic log of the Andrés outcrop. Legend: A1 - Coarse sandy deposits without mica; A2 - medium to fine sandy layers with low-angle cross-bedding; L1 - massive or laminated clays and silts, mostly reddish or mottled; L2 - Fine sands, frequently laminated and intercalated with millimetre to centimetre thick silts and clays. b) Reconstruction of a fluvial-terrestrial environment that corresponds to the palaeoenvironmental interpretation in the area of the quarry.

Fig. 2.- a) Columna litoestratigráfica del afloramiento en el área del yacimiento de Andrés. Leyenda: A1 - depósitos arenosos groseros sin mica; A2 - capas de arenisca de grano medio a fino con laminación cruzada de bajo ángulo L1 - niveles de arcillas y limos compactos o laminados, por veces rojos o moteados; L2 - areniscas finas, a veces laminadas y intercaladas con niveles finos de arcillas y limos. b) Reconstrucción de un ambiente terrestre fluvial que corresponde a la interpretación paleoambiental en el área del yacimiento.

This facies association clearly indicates a medium to high-sinuosity fluvial system, with multiple channels and crevasses in a large floodplain. Seasonal climatic contrasts promoted repeated situations of immersion and emersion, testified by hidromorphic features and carbonate rhizogenic concretions developed in the floodplain clays. The sedimentological characteristics of these deposits suggest a freshwater environment located in a shallow meandering river system (Fig. 2), with low energy but still far away from the coastal influences of a deltaic system, recognized some tens of kilometres more to the west (Pimentel, 2009).

Occasionally, some very complete skeletons of tiny animals (fishes and lepidosaurs) have been found. Some partially articulated or non-dispersed skull bones and elements of the axial series of Allosaurus are recovered too. The orientation of the elongated bones of Allosaurus allows determining an almost $\mathrm{E}$ to $\mathrm{W}$ direction for the palaeodrainage at the site of the quarry. This direction is corroborated by the orientation of the channels, as perceived in outcrop, and also by the regional palaeogeographic reconstruction, with uplifted areas located to the East of the basin (Pimentel, 2009).

\section{Material and methods}

The set of fossils described in the present work is part of the collection of vertebrate palaeontology of the Museu Nacional de História Natural - Universidade de Lisboa (MNHN-UL). The specimens are identified with the reference MNHNUL/AND, and are deposited in this museum.

\section{Institutional abbreviations}

MNHNUL - Museu Nacional de História Natural (Universidade de Lisboa); USNM - United States National Museum

\section{Vertebrate diversity}

The dinosaur remains, mainly those attributed to $\mathrm{Al}$ losaurus, are at the moment the most abundant in the site. Although it has been also identified several representatives of other vertebrate taxa. It was recognized a diversity of vertebrate fauna composed by semionotiform fishes, at least one lepidosaur taxon, and representatives of three groups of archosaurs, such as crocodylomorphs, pterosaurians and dinosaurs.

\subsection{Fishes}

Fish remains are mainly represented by isolated rhombic scales, but occasionally more complete specimens have been recognized. It was recovered an almost complete individual of a Lepidotes-like semionotiform preserved in a clay lens (Fig. 3). This specimen presents a fusiform and fairly elevated body, with a maximum height situated between the posterior end of the skull and the dorsal fin, corresponding approximately to $30 \%$ of the total length. The skull is short, about one third of the total length of the body. This specimen is one of the rare occurrences of articulated semionotiform fish from the Portuguese record, highlighting the singularity of the conditions of preservation at the site.

\subsection{Lepidosaurs}

Cranial and postcranial bones of lepidosaurs are very common in some restricted areas of the quarry. The set of lepidosaur remains represent several individuals, probably belonging to a unique form. The most complete specimen has preserved the complete skull and the cranial part of the articulated postcranial skeleton (Fig. 4). Some other collected remains from the same area may also belong to the same individual. The sphenodontian specimens from Andrés constitute the first evidence of this group of rep- 
tiles in the Iberian Peninsula. A preliminary analysis of this set of material suggests that it belongs to a close relative to the genus Opisthias, at the moment cited in both, the North American and European records (Ortega et al., 2006).

\subsection{Crocodylomorphs}

Crocodylomorphs are represented by cranial and postcranial elements mainly identified as indeterminate neosuchians. The cranial material includes abundant teeth (Fig. 5a) and several maxillary fragments, sometimes very complete. Concerning to the postcranial remains, at the moment it is represented only by abundant osteoderms. The teeth have conical crowns, with a relatively blunt apex. The crowns present well-developed wrinkled striae running from the base to the apex. These remains are similar to others assigned to a close relative to the genus Goniopholis also known from other Portuguese Upper Jurassic sites, such as the Guimarota coalmine. Some Goniopholis specimens from Guimarota were attributed to a particular species G. baryglyphaeus (Schwarz, 2002). At the moment, it was not possible to make deeper comparisons between the Andrés and Guimarota specimens, but probably both belong to close forms. The Portuguese Goniopholis specimens constitute the oldest evidence of this genus known at the moment in Europe and suggest also a larger area of distribution of these neosuchians than previously thought (Schwarz, 2002).

Some very small and lanceolated teeth collected in Andrés correspond to a second crocodile morphotype. These teeth have a characteristic ornamentation based on delicate ridges that are parallel at their bases but diverge toward the apex. Some of these ridges end on the mesial or distal carinae. This type of teeth is typically assigned to Atoposauridae close related to members of the genus Theriosuchus. As occurs with Goniopholis, a particular species of Theriosuchus, T. guimarotae has been described in Guimarota (Schwarz and Salisbury, 2005) but at present no comparison can be made with the Andrés specimens.

\subsection{Pterosaurs}

Pterosaurs are represented by some long and thin teeth (Fig. 5b). These teeth present straight crowns, with rounded cross-section, and strongly tapered to the apex. The surface of the crown is smooth, without ornamentation, differing from almost all the pterodactiloid ornithocheirids. Pterosaur remains are very scarcely known in the Portuguese Upper Jurassic record. The pterosaurs teeth from Andrés have a needle-like general morphology similar to some teeth described from Guimarota and tentatively assigned to Rhamphorhynchus (Wieckmann and Gloy, 2000).

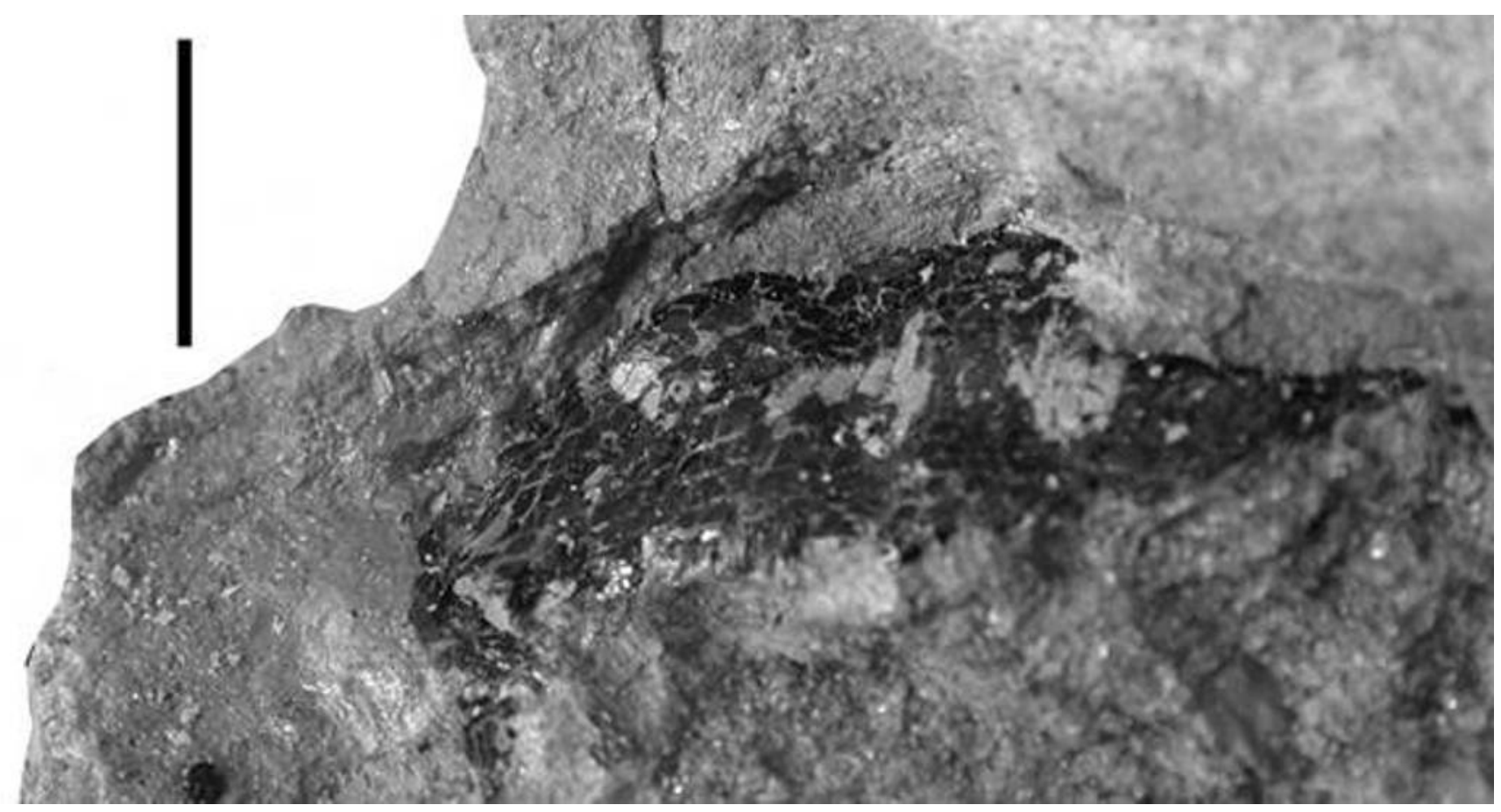

Fig. 3. - Individual of Lepidotes-like semionotiform preserved in a clay lens. Scale: $10 \mathrm{~mm}$

Fig. 3. - Individuo de semionotiforme afín a Lepidotes conservado en un lentejón de arcilla. Escala: 10mm. 


\subsection{Dinosaurs}

The dinosaur elements, especially those assignable to Allosaurus, are at the moment the most abundant among the fossils collected in the quarry. The major diversity is verified among the sauropods. The collected sample is composed by at least seven different dinosaur forms, most of which is based in dental morphotypes that belong to theropods, sauropods, and ornithopods.

Orntithischians are represented by at least two ornithopod forms. Most of the remains identified are isolated teeth and a set of postcranial bones, the latter belonging to a small ornithopod dinosaur. The best preserved and complete tooth (Fig. 5c) is rhomb shaped, with a prominent primary ridge in the labial surface and several slight subsidiary ridges anterior to the former. These teeth presents well developed denticles on both mesial and distal carinae. Teeth with these characteristics are common in derived iguanodontians such as the camptosaurids (Norman, 2004).

Camptosaurid-like teeth from the Portuguese Upper Jurassic were previously assigned to Draconyx from the locality of Vale Frades, in Lourinhã (Mateus and Antunes, 2001). Since there are no diagnostic features to differentiate Draconyx and Camptosaurus teeth, there is not possible at the moment to attribute the specimens from Andrés to one of them. These specimens are thus assigned as undetermined camptosaurid ornithopod (Ortega et al., 2009).

A set of autopodial bones and a dorsal vertebra belonging to small ornithopods were also identified. The autopodial remains are interpreted as two phalanges I, of the digits I and III, and one pedal ungueal. The vertebra is complete and corresponds to a posterior dorsal. This vertebra presents elongated transverse processes. The total width over the maximum width of the anterior face of the centrum is 3:1, a feature shared with Dryosaurus (Galton, 1981). From the Portuguese Upper Jurassic record, two small dryosaurids have been briefly described, a partial skeleton referred as closely related to Dryosaurus (Dantas et al., 2000) from Porto das Barcas (Lourinhã); and a right dentary with teeth from Zimbral (Lourinhã) assigned as aff. Dryosaurus (Mateus, 2007). Although small dryosaurids have been identified in the Portuguese

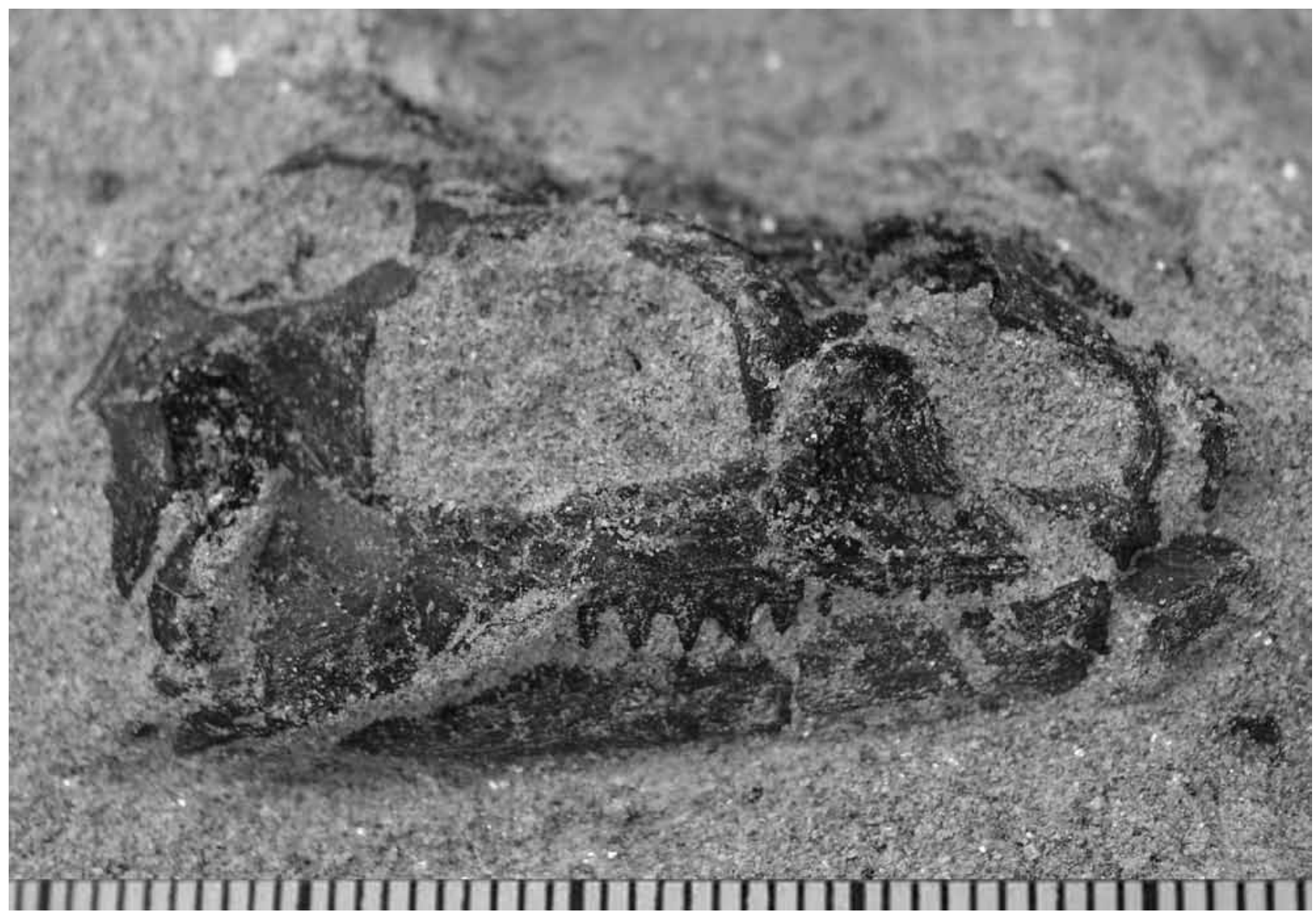

Fig. 4. - Sphenodont skull, in right lateral view.

Fig. 4. - Cráneo de esfenodonto en vista lateral derecha. 


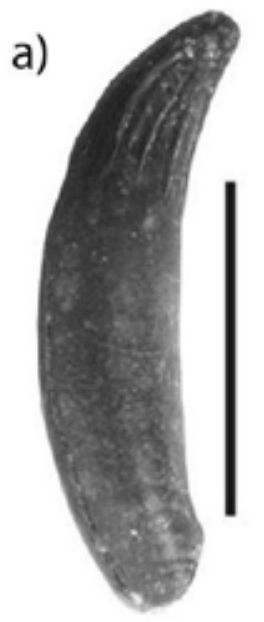

b)
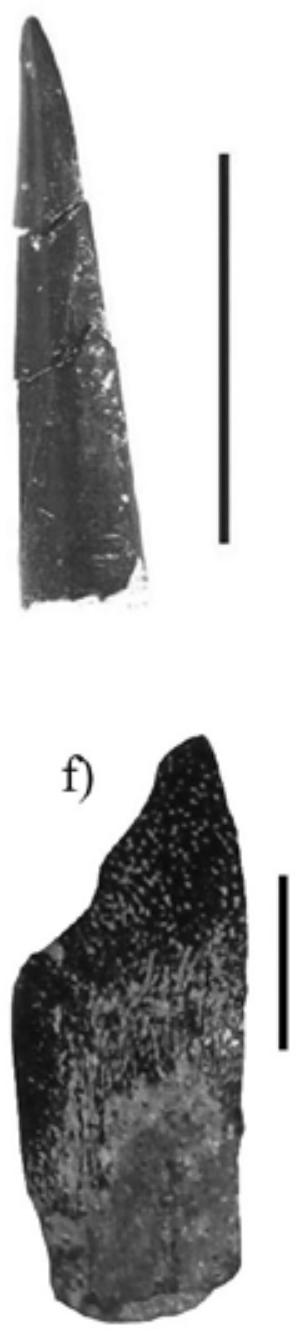

c)

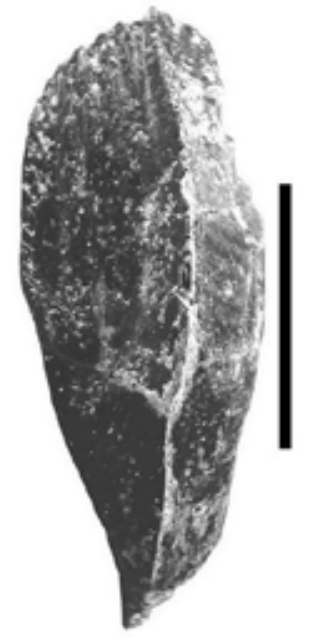

g)

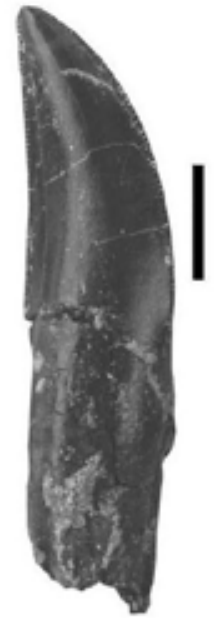

d)

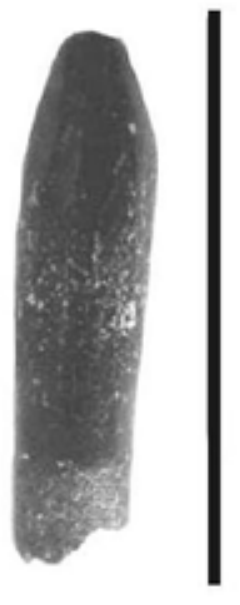

h)

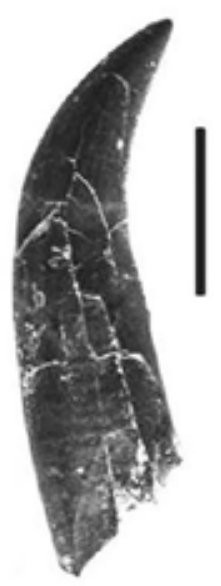

Fig. 5. - Teeth collected on the Andrés fossil-site. a) Goniopholis sp.; b) indeterminate pterosaur; c) camptosaurid ornithopod; d) titanosauriform sauropod; e) diplodocid sauropod; f) indeterminate neosauropod; g) Allosaurus sp.; h) dromaeosaurid theropod. Scale: 10 mm Fig. 5. - Dientes recogidos en el yacimiento de Andrés. a) Goniopholis sp.; b) pterosaurio indeterminado; c) ornitópodo camptosaurideo; d) saurópodo titanosauriforme; e) saurópodo diplodócido; f) neosauropodo indeterminado; g) Allosaurus sp.; h) terópodo dromaeosaurido. Escala: $10 \mathrm{~mm}$

Upper Jurassic record (Ortega et al., 2009), here we prefer to refer these specimens as an undetermined form closely related to Dryosaurus, pending to find more diagnostic material.

Sauropods are represented by isolated teeth and some postcranial remains. The most abundant sample is composed by chisel-shape teeth with a rounded cross-section and straight crown assigned to a titanosauriform morphotype (Fig. 5d).

It was also collected some pencil-shape teeth, similar to that assigned to Diplodocoidea (Fig. 5e). Some spoonshape, mostly incomplete, teeth (Fig. 5f) were also abundant in Andrés. These teeth have morphology similar to that described in the neosauropod Turiasaurus from the Tithonian - Berriasian of Spain (Royo-Torres et al., 2006). Also interpreted as belonging to a juvenile neosauropod are some isolated pelvic bones and a centrum of a dorsal vertebra.

The theropods are the best represented dinosaur group due to the identification of abundant elements of at least two individuals assignable to Allosaurus. The recently recovered specimens increment substantially the collection of Allosaurus remains previously described from the site (Fig. 5g).

Theropod teeth with morphology usually attributed to dromaeosaurids were also collected in Andrés. These teeth are very laterally compressed and present a strong distal curvature of the crowns. They also present denticles 
on both distal and medial carinae, which are restricted to the apices in the medial edge while distally it extends until the base of the crown (Fig. 5h).

The Allosaurus specimen described in 1999 and assigned to the species $A$. fragilis comprehend some cranial remains (the posterior end of a right frontal, the articular region of a right quadrate and some teeth), some vertebrae, dorsal and ventral ribs, most of the pelvic girdle and hindlimb elements and several indeterminate fragments (Pérez-Moreno et al., 1999; Dantas et al., 1999). At the moment, it was possible identify several new cranial and postcranial remains assignable to Allosaurus, as a right quadrate-quadratojugal (Fig. 6a), two lacrimals (Fig. 6b), a right dentary, a right frontal, the posterior end of a right mandibular ramus and a complete braincase (Fig. 6c). These cranial elements were collected at the same level, near to the remains previously described and probably correspond to the same individual. However, a complete ilium also collected from this site probably belongs to a second, larger individual.

Based on the method of Seebacker (2001) to calculate allometric length-mass relationships of dinosaurs, as well as on the comparison with other described specimens, the most complete Allosaurus specimen from Andrés would have about $6,5 \mathrm{~m}$ in length and an estimated mass of $850 \mathrm{~kg}$. These dimensions fall on the gap of estimated size for some North American adult Allosaurus individuals, compare for example with the specimen USMN 4734, described by Madsen (1976), with 7,4m in length and a mass of $952 \mathrm{~kg}$.

The description of Allosaurus fragilis in the Andrés quarry was first based mainly in the characters combination available from the pelvic girdle and hindlimb elements. These characters include: 1) large pubic peduncle of the ilium, longer than wide and much longer than the ischiatic peduncle; 2) obturator process of the ischium large, tapering and projected cranially to the level of the puboischiatic contact; 3 ) presence of a small notch that separates the caudodistal margin of the obturator process from the ischiatic shaft; 4) pubis with a large distal boot, which presents a well developed cranial and caudal expansion; and 5) moderately high ascending process of the astragalus (Pérez-Moreno et al., 1999).

The preliminary analysis of the new material, as well as the revision of the previously described specimen, support the former proposed identification of the Andrés specimens as belonging to the genus Allosaurus. The available material shares with some North American forms a set of autapomorphies that include: a) lacrimal with a caudal margin of the preorbital ramus concave and without a projection into the orbit; b) lacrimal with a well developed cornual process, which projects substantially above the skull table; c) squamosal with a ventral ramus that runs down the cranial margin of the quadrate and reaches at least half the height of the lateral temporal fenestra; d) squamosal with a series of striations on the lateral surface of the descending process; e) parietals with a notch in the dorsal end that separates it from the supraoccipital; f) paroccipital processes caudoventrally and laterally oriented, with the distal ends well projected below the level of the occipital condyle; g) basisphenoid separated from the basal tubera by a groove (Madsen, 1976; Chure, 2000).

The analysis of the set of material assignable as $\mathrm{Al}$ losaurus from Andrés allows identifying a combination of characters compatible with the variability previously known for the $A$. fragilis species from the North American Morrison Formation (Chure, 2000; Madsen, 1976; Malafaia et al., 2009a).

A new species of Allosaurus, A. europaeus was recently described on the base of a posterior part of a skull collected at the Upper Jurassic of Vale Frades, near Lourinhã (Mateus et al., 2006). The set of characters referred as distinctive for the proposed new species is composed by a series of states which falling into the morphological variability of $A$. fragilis, as well as by some probably misinterpreted features. The characters more definitive for the diagnose of the new species, the anterior relation of the jugal, lacrimal and maxilla, can be derivate from a misinterpretation of a fracture line in the ventral part of the lacrimal as the suture between the lacrimal and the maxilla (Malafaia et al., 2009a). Thus, we prefer, based on this argumentation, to consider A. europaeus as a nomen dubium until more accurate description of the type specimen.

The currently known Portuguese record of dromaeosaurids is very scarce and these theropods are only represented by some teeth described from the Guimarota coalmine, and by scarce elements collected in the Upper Cretaceous from the northern area of the Lusitanian Basin (Galton, 1996; Zinke, 1998). The collection of dromaeosaurid teeth from Guimarota includes a premaxillary tooth assigned as cf. Dromaeosaurus and several teeth referred to velociraptorine dromaeosaurids (Rauhut, 2000; Zinke, 1998).

The specimens from Andrés present some resemblance with the teeth assigned to Dromaeosaurus, as the twist of the anterior carina and the size and shape of the denticles (Currie et al., 1990). Based on these characters, it is considered the presence in Andrés of a representative of the dromaeosaurids that shares some conditions with Dromaeosaurus. 


\section{Palaeobiogeographical approach}

The Andrés quarry constitutes one of the relatively most diverse ecosystems currently known for the continental Upper Jurassic record from Portugal. An important result from the analysis of the collected vertebrate remains consists in the identification of specimens assignable to Allosaurus, one of the best-known neotetanuran genera. The most recently analysed elements, mainly a set of cranial bones, also suggest a close similarity between the specimens from Andrés and some members attributed to $\mathrm{Al}$ losaurus fragilis. This hypothesis has important implications for the knowledge of the palaeobiogeographic role of the Iberian plate during the Upper Jurassic. The description of Allosaurus fragilis in the Andrés quarry constitutes one of the stronger evidence supporting the similarity between North American and Portuguese dinosaur faunas during the upper Kimmeridgian-Tithonian. This similarity is also supported by the presence of other taxa, as the theropods Ceratosaurus and Torvosaurus (Mateus et al., 2006) or the ornithischian Stegosaurus (Escaso et al., 2007) from others sites of the Lusitanian Basin.

Other elements compounding the collection of vertebrate fossils from the Andrés quarry, may contribute with new data for the palaeobiogeographic interpretation of these faunas. This is the case for example of the abundant and sometimes very well preserved, sphenodontian specimens whose relationship with members of the genus Opisthias described in North America and Europe is now in study (Ortega et al., 2006).

Some recent tectonic and sedimentological analysis demonstrate the occurrence of a regional regressive phase during the uppermost Kimmeridgian - lowermost Tithonian related with the opening of the northern sector of a)

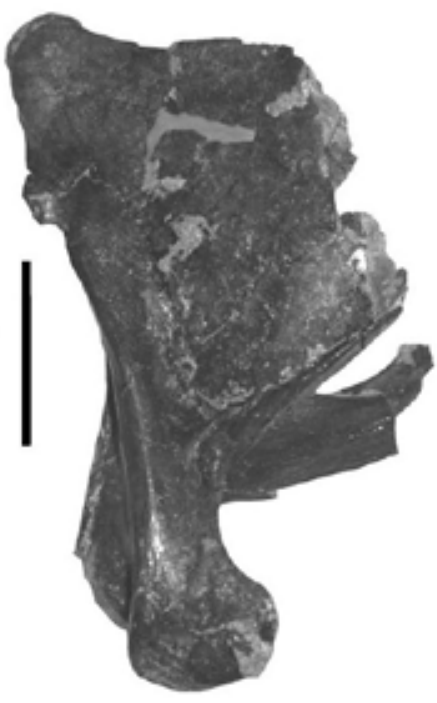

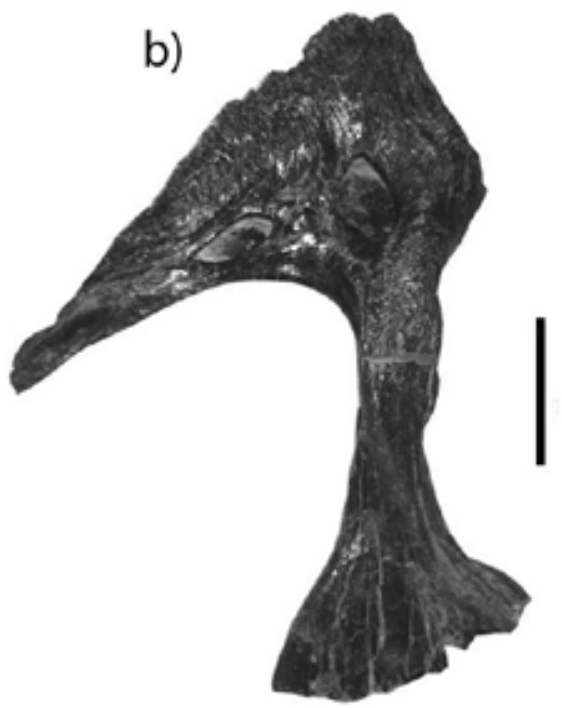

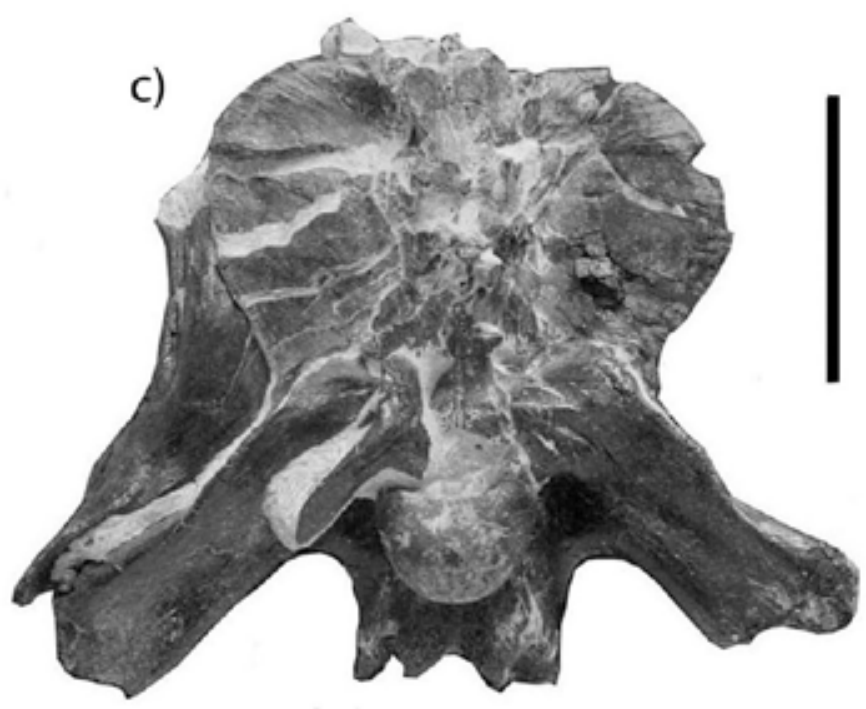

Fig. 6. - Some elements assignable as $\mathrm{Al}$ losaurus collected on the Andrés fossilsite. a) Right quadrate and quadratojugal in medial view; b) Left lacrimal in medial view; c) Braincase in occipital view. Scale a) and b): $50 \mathrm{~mm}$; c): $100 \mathrm{~mm}$.

Fig. 6. - Algunos de los elementos asignados a Allosaurus recogidos en el yacimiento de Andrés. a) Cuadrado y cuadradoyugal derechos en vista medial; b) Lacrimal izquierdo en vista medial; c) Basicráneo en vista occipital. Escala a) y b): $50 \mathrm{~mm}$; c): $100 \mathrm{~mm}$. 
the Atlantic Ocean (Kullberg, 2006; Escaso et al., 2007). This regional process, opposite to the global transgression noted on this time interval, have probably favoured the increase of emerge areas between the continental masses on both sides of the incipient north-Atlantic. At the moment, it is considered, that this tectonic hypothesis suggesting favourable conditions for circulation of continental faunas between Iberia and North America during the Upper Jurassic is the best scenario for explain the known continental vertebrate distribution from the Portuguese record (Escaso et al., 2007).

\section{Conclusions}

The set of material studied from the Andrés fossil-site allows identifying the presence of at least five major vertebrate groups: fishes, lepidosaurs, crocodylomorphs, pterosaurs, and seven different forms of dinosaurs. The vertebrate remains recovered in this quarry constitute an increment of the available data for the knowledge of continental ecosystems developed during the Upper Jurassic in the Iberian Peninsula, due to its abundance and the identification of some taxa at the moment unknown on any other Iberian site, as the sphenodonts.

The identification of abundant Allosaurus remains suggests a distribution of this neotetanuran in Laurasia wider than it was considered during several decades. The record of Allosaurus from the Portuguese Upper Jurassic at the moment allows recognizing this taxon as a common theropod among vertebrate communities from the Iberian Peninsula (Mateus et al., 2006; Malafaia et al., 2009b). An important set of material, whose study is at present in progress, containing abundant and well preserved cranial bones, constitutes a strong basis for phylogenetic analysis. At the moment, all the analysed specimens present several similarities with members of $A$. fragilis (Malafaia et al., 2007).

The presence of Allosaurus specimens in the Portuguese Upper Jurassic strengthens the previously hypothesis that suggests a great similarity between vertebrate faunas developed in occidental Europe, particularly in Iberia and North America during the Upper Jurassic (Galton, 1980a,b; Galton and Powell, 1980; Pérez-Moreno et al., 1999; Dantas at al., 1999; Rauhut, 2003; Escaso et al., 2007). The palaeogeographic hypothesis suggesting the existence of some kind of contacts between continental vertebrate faunas from both sides of the proto northAtlantic seems to be actually the best scenario for explain the Upper Jurassic record of some tetrapods groups from Portugal.

\section{Acknowledgements}

Acknowledgements for the participation in different aspects of the works developed in the Andrés fossil-site to António M. Galopim de Carvalho, Mauro García-Oliva, Cristina Moniz, Adán Pérez García, Liliana Póvoas, Graça Ramalheiro, Bruno Ribeiro and Jesús Santamaría. This work was developed in the context of the projects POCTI/ 1999/ PAL/ 36550- "Dinosaur Osteological and Ichnological studies of the Mesozoic of Portugal (DINOS)" and PTDC/ CTE-GEX/ 67723/ 2006 "Estudo da Fauna de Vertebrados do Jurássico Superior da Bacia Lusitânica e Implicações Paleobiogeográficas (VERT-JURA)" both financed by the "Fundação para a Ciência e a Tecnologia" (Portugal). Others institutions involved in the financing of the field activities or investigation of the authors are: a collaboration protocol of the Museu Nacional de História Natural - Universidade de Lisboa (MNHN-UL) with the Junta de Freguesia de Santiago de Litém (Pombal, Portugal) and other between the MNHN-UL and the Câmara Municipal da Batalha (Portugal). The work of the first author (EM) was also supported by a fund of the Jurassic Foundation and Fundação Luso-Americana.

\section{References}

Chure, D.J. (2000): A new species of Allosaurus from the Morrison Formation of Dinosaur National Monument (UT-CO) and a revision of the Theropod family Allosauridae. PhD Thesis. Columbia University: $964 \mathrm{p}$.

Currie, P.J., Rigby, Jr., J.K., Sloan, R. (1990): Theropod teeth from the Judith River Formation of southern Alberta, Canada. In: Carpenter, K., Currie, P.J. (eds.). Dinosaur Systematics: Approaches and Perspectives. Cambridge University Press, New York, 107125. http://dx.doi.org/10.1017/CBO9780511608377.011

Dantas, P., Pérez-Moreno, B.P., Chure, D.J., da Silva, C.M., dos Santos, V.F., Povoas, L., Cachão, M., Sanz, J.L., Pires, C., Bruno, G., Ramalheiro, G., Galopim de Carvalho, A.M. (1999): O dinossáurio carnívoro Allosaurus fragilis no Jurássico português. Al-Madam 8: 23-28.

Dantas, P., Yagüe, P., Hazevoet, C.J., Ortega, F., Santos, V.F., Sanz, J.L., Cachão, M., Galopim de Carvalho, A.M., Santos, J.J. (2000): Um novo Iguanodontia basal do Jurássico Superior português. Abstracts XVI Jornadas de la Sociedad Española de Paleontologia, Évora: 12-13.

Escaso, F., Ortega, F., Dantas, P., Malafaia, E., Pimentel, N.L., Pereda-Subelbiola, X., Sanz, J.L., Kullberg, J.C., Kullberg, M.C., Barriga, F. (2007): New evidence of shared Dinosaur Across Upper Jurassic Proto-North Atlantic: Stegosaurus from Portugal. Naturwissenschaften, 94(5): 367-374. http://dx.doi. org/10.1007/s00114-006-0209-8

Galton, P.M. (1980a): Dryosaurus and Camptosaurus, intercontinental genera of Upper Jurassic ornithopod dinosaurs. Memoirs of the Geological Society of France, NS, 139: 103-108.

Galton, P.M. (1980b): European Jurassic ornithopod dinosaurs of 
the families Hypsilophodontidae and Camptosauridae Neues Jahrbuch Für Geologie Und Paläontologie Abhandlungen, 160: 73-95.

Galton, P.M. (1981): Dryosaurus, a hypsilophodontid dinosaur from the Upper Jurassic of North America and Africa: Postcranial skeleton. Paläontologische Zeitschrift, 55: 271-312.

Galton, P.M. (1996): Notes on Dinosauria from the Upper Cretaceous of Portugal. Neues Jahrbuch Für Geologie Und Paläontologie Monatshefte: 83-90.

Galton, P.M., Powell, P. (1980): The Ornithischian Dinosaur Camptosaurus prestwichii from the Upper Jurassic of England. Palaeontology, 23: 411-443.

Kullberg, J.C., Rocha, R.B., Soares, A.F., Rey, J., Terrinha, P., Callapez, P., Martins, L. (2006): A Bacia Lusitaniana: Estratigrafia, Paleogeografia e Tectónica. In: Dias, R., Araújo, A., Terrinha, P., Kullberg, J.C. (eds) Geologia de Portugal no contexto da Ibéria, Universidade Évora: 317-368.

Madsen, J.H. (1976): Allosaurus fragilis: a revised osteology. Utah Geological and Mineral Survey, 109: 163 p.

Malafaia, E., Dantas, P., Ortega, F., Escaso, F. (2007): Nuevos restos de Allosaurus fragilis (Theropoda: Carnosauria) del yacimiento de Andrés (Jurásico Superior; Centro-Oeste de Portugal). In: Cambra-Moo, O., Martínez-Pérez, C., Chamero, B., Escaso, F., de Esteban Trivigno, S., Marugán-Lobón, J. (eds.), Cantera Paleontológica: 255-271. Diputación Provincial de Cuenca, Cuenca: 398 p.

Malafaia, E., Ortega, F., Escaso, F., Dantas, P., Gasulla, J.M. (2009a): Allosaurus fragilis from the Portuguese Upper Jurassic. Journal of Vertebrate Paleontology, 29(Supplement to Number 3): 140-141A.

Malafaia, E., Ortega, F., Escaso, F., Silva, B., Ramalheiro, G., Dantas, P., Moniz, C., Barriga, F. (2009b): Análisis preliminar de un nuevo ejemplar de Allosaurus del Grupo Lourinhã (Jurásico Superior de Torres Vedras, Portugal). In: Colectivo Arqueológico y Paleontológico de Salas (ed.), Actas de las IV Jornadas Internacionales sobre Paleontología de Dinosaurios y su Entorno. Salas de los Infantes, Burgos: 243-251.

Manuppella, G., Barbosa, B., Machado, S., Carvalho, J., Bartolomeu, A., Azerêdo, A.C., Ramalho, M., Crosaz, R., Baptista, R., Porteiro, A., Dâmaso, B., Cunha, T.A. (1998): Carta Geológica de Portugal, folha 27-A (Vila Nova de Ourém). Escala 1:50 000 ( $2^{\mathrm{a}}$ ed.). Instituto Geológico e Mineiro, Lisboa.

Manuppella, G., Rodrigues, A., Oliveira, J., Carreira de Deus, P. (1974): Carta Geológica de Portugal, folha 23-A (Pombal). Escala 1: 50000 ( $1^{\mathrm{a}} \mathrm{ed}$.). Serviços Geológicos de Portugal. Lisboa.

Manuppella, G., Telles Antunes, M., Costa Almeida, C.A., Azerêdo, A.C., Barbosa, B., Cardoso, J.L., Crispim, J.A., Duarte, L.V., Henriques, M.H., Martins, L.T., Ramalho, M.M., Santos, V.F., Terrinha, P. (2000): Notícia Explicativa da Carta Geológica de Portugal, folha 27-A (Vila Nova de Ourém). Escala 1: $50000\left(2^{\mathrm{a}}\right.$ ed.). Instituto Geológico e Mineiro, Lisboa.

Manuppella, G., Zbyszewski, G. and da Veiga Ferreira, O. (1978): Notícia Explicativa da Carta Geológica de Portugal, da folha 23-A (Pombal). Escala 1: 50000 (1 $1^{\mathrm{a}}$ ed). Serviços Geológicos de Portugal, Lisboa.

Marques, B., Olóriz, F., Caetano, P.S., Rocha, R., Kullberg, J.C. (1992): Upper Jurassic of Alcobaça Region. Stratigraphic Contributions. Comunicações Serviços Geológicos de Portugal, 78(1): 63-69.
Martin, T., Krebs, B. (2000): Guimarota: A Jurassic ecosystem. Verlag Dr. Friedrich. Pfeil, Munich: 155 p.

Mateus, O. (2007): Notes and review of the ornithischian dinosaurs of Portugal. Journal of Vertebrate Paleontology, 27(Supplement to Number 3): 114A.

Mateus, O., Antunes, M.T. (2001): Draconyx loureiroi, a new camptosauridae (Dinosauria, Ornithopoda) from the Late Jurassic of Lourinhã, Portugal. Annales de Paléontologie, 87(1): 61-73. http://dx.doi.org/10.1016/S0753-3969(01)88003-4

Mateus, O., Walen, A., Antunes, M.T. (2006): The large theropod fauna of the Lourinhã Formation (Portugal) and its similarity to the Morrison Formation, with a description of a new species of Allosaurus. New Mexico Museum of Natural History and Science Bulletin, 36: 123-129.

Norman, D.B. (2004): Basal Iguanodontia. In: Weishampel, D.B., Dodson, P., Osmolska, H. (eds.). The Dinosauria 2nd Edition: 413-437. University of California Press, Berkeley: 413-437.

Ortega, F., Dantas, P., Escaso, F., Gasulla, J.M., Malafaia, E., Ribeiro, B. (2006): Primera cita de reptiles esfenodontos en el Jurásico Superior de la Península Ibérica. Resúmenes XXII Jornadas de Paleontología, León: 152-153.

Ortega, F., Malafaia, E., Escaso, F., Dantas, P., Pérez García, A. (2009): Faunas de répteis do Jurássico Superior de Portugal. In: Pérez García, A., Silva, B.C., Malafaia, E., Escaso, F. Paleolusitana 1. Associação Leonel Trindade-Sociedade de História Natural, Torres Vedras: 43-56.

Pérez-Moreno, B.P., Chure, D.J., Pires, C., da Silva, M.C., dos Santos, V., Dantas, P., Povoas, L., Cachão, M., Sanz, J.L., de Carvalho, A.M.G. (1999): On the presence of Allosaurus fragilis (Theropoda, Carnosauria) in the Upper Jurassic of Portugal: first evidence of an intercontinental dinosaur species. Journal of the Geological Society of London, 156: 449-452. http://dx.doi. org/10.1144/gsjgs.156.3.0449

Pimentel, N.L. (2009): Contextualização paleogeográfica das jazidas de vertebrados do Jurássico Superior da Bacia Lusitânica. In: Pérez García, A., Silva, B.C., Malafaia, E., Escaso, F. Paleolusitana 1. Associação Leonel Trindade-Sociedade de História Natural, Torres Vedras: 465-470.

Rauhut, O.W.M. (2000): The dinosaur fauna from the Guimarota mine. In: T. Martin, B. Krebs (eds.), Guimarota: A Jurassic ecosystem. Verlag Dr. Friedrich. Pfeil, Munich: 75-82.

Rauhut, O.W.M. (2003): A tyrannosauroid dinosaur from the Upper Jurassic of Portugal. Palaeontology, 46(5): 903-910. http:// dx.doi.org/10.1111/1475-4983.00325

Royo-Torres, R., Cobos, L., Alcalá, L. (2006): A giant European dinosaur and a new sauropod clade. Science, 314: 1925-1927. http://dx.doi.org/10.1126/science.1132885

Schwarz, D. (2002): A new species of Goniopholis from the Upper Jurassic of Portugal. Palaeontology, 45(I): 185-208. http:// dx.doi.org/10.1111/1475-4983.00233

Schwarz, D., Salisbury, S.W. (2005): A new species of Theriosuchus (Atoposauridae, Crocodylomorpha) from the Late Jurassic (Kimmeridgian) of Guimarota, Portugal. Geobios, 38(6): 79802. http://dx.doi.org/10.1016/j.geobios.2004.04.005

Seebacker, F. (2001): A new method to calculate allometric length-mass relationships of dinosaurs. Journal of Vertebrate Paleontology, 21(1):51-60. http://dx.doi.org/10.1671/02724634(2001)021[0051:ANMTCA]2.0.CO;2

Teixeira, C., Camarate França, J., Zbyszewski, G., da Veiga Fer- 
reira, O., de Matos, M., Oliveira, J., Rodrigues, L., Rodrigues, A., Manuppella, G. (1966): Carta Geológica de Portugal, folha 23-C (Leiria). Escala 1: 50000 ( $1^{\mathrm{a}}$ ed.). Publicações dos Serviços Geológicos de Portugal. Lisboa.

Teixeira, C., Zbyszewski, G., Torre de Assunção, C., Manuppella, G. (1968): Notícia Explicativa da Carta Geológica de Portugal, folha 23-C (Leiria). Escala 1: 50000 ( $1^{\mathrm{a}} \mathrm{ed}$.). Publicações dos Serviços Geológicos de Portugal, Lisboa.
Wiechmann, M.F., Gloy, U. (2000): Pterosaurs and urvogels from the Guimarota mine In: T. Martin, B. Krebs (eds.), Guimarota: A Jurassic ecosystem. Verlag Dr. Friedrich Pfeil, Munich: 83-86. Zinke, J. (1998): Small theropod teeth from the Upper Jurassic coal mine of Guimarota (Portugal). Paläontologische Zeitschriff 72(1/2): 179-189. 